\title{
Bacterial community establishment in native and non-native soils and the effect of fungal colonization
}

\author{
Rashid Nazir ${ }^{1,2^{*}}$, Alexander V. Semenov ${ }^{1}$, Nermin Sarigul ${ }^{1}$ and Jan Dirk van Elsas ${ }^{1}$ \\ *Correspondence: r.nazir@rug.nl \\ 'Department of Microbial Ecology, University of Groningen Nijenborgh 7, 9747 AG, Groningen, Netherlands. \\ ${ }^{2}$ Department of Environmental Sciences, COMSATS Institute of Information Technology, Abbottabad, Pakistan.
}

\begin{abstract}
Bacterial communities are essential parts of living soils. However, we understand very little of how soil matrices govern the structure of the local microbiota. Here, we report on experiments that address such assembly rules for microbial communities in soil. Thus, indigenous soil bacterial communities were extracted from eight different soils (denoted V, B, G, WD, L, K, S and WG) and used to inoculate four selected presterilized sandy soils (V, B, G and WD) in microcosms. Then, these microcosms were subjected to colonization by the soil saprotrophic fungus Lyophyllum sp. strain Karsten, or were left uncolonized. Fifteen days following introduction, the microcosms were analyzed to enumerate culturable (dilution plating) and total bacteria (quantitative PCR) and bacterial community structures (PCR-DGGE), to assess the abundance and diversity of the bacterial communities. Moreover, fungal-selected culturable bacteria were identified. In all cases and irrespective of the presence of fungal mycelium, bacterial communities of around $1-5 \times 10^{8} \mathrm{CFU}$ or $16 \mathrm{~S}$ rRNA gene copies per g dry soil established. The data further clearly showed the influence of local soil conditions on the establishment of the inoculant bacteria in their native versus non-native soil. Thus, cluster analysis of the PCR-DGGE fingerprints revealed that two soils, i.e., $\mathrm{V}$ and B, were strong drivers of the established community structures from the eight source communities, whereas the two remaining soils (G and WD) revealed mixed effects. PCR-DGGE further revealed that the non-native bacterial communities obtained from sandy source soils were more similar to the established native communities than those from clayey soils. Overall, the bacterial communities showed decreased diversities and richness values in the fungal-colonized systems as compared to the non-fungal-affected ones (inoculation and migration sites). In the fungal-affected systems, the recipient soil matrix was of importance, in particular at the inoculation site of the $\mathrm{V}$ and $\mathrm{B}$ soil matrices and at the migration front of the $\mathrm{G}$ matrix. Analysis of the culturable bacterial community across different soils revealed that similar bacteria, even originating from different sources, were enriched by the colonizing fungus. Particular bacterial types, like Burkholderia and Pseudomonas spp., were found to be selected by the growing fungal hyphae. Further more, an enrichment of type three secretion systems (TTSS) was detected.
\end{abstract}

Keywords: Bacterial community establishment, native and non-native soils, fungal colonization effect, bacterial enrichment, type three secretion system (TTSS)

\section{Introduction}

Soil is usually characterized as a complex dynamic system, in which bacteria and fungi live together [12]. These organisms thus occupy the available niche space $[9,4]$ by utilizing the nutrients that are ultimately provided by autotrophic plants or decaying organisms as well as from each other. The microsites in soil where bacteria and fungi meet are called bacterial-fungal interfaces [9]. These are proposed to represent ecological hot spots where the heat of interactions is presumed to occur. A better analysis of such hot spots will enable us to understand the interactions between these two important groups of soil microorganisms. Thus, living together in soil, bacteria and fungi have been hypothesized to exert specific effects on each other [12]. The locally-specific conditions that drive the selective processes in these soil bacterial/fungal hot spots may be quite dependent on soil type.

The microbiota of each soil may, thus, be unique for that particular soil, as it has evolved and matured over the time of existence of the soil. Unfortunately, we currently lack detailed knowledge on how indigenous microbial communities are shaped in accordance with the dynamics of the local habitat. Moreover, in the light of the uncertainty on the exact nature of the niche spaces in soil, it is unclear to what extent particular bacterial groups are favored or disfavored in soils. On top of this, an important impact by soil fungi can be expected to occur for soil bacterial communities [19]. Examined bacterial and arbuscular mycorrhizal (AM) fungal assemblages in soil and concluded that fungi are indeed major determinants of the local bacterial assemblages. Early work by Artursson and colleagues $[\mathbf{1 , 2}]$ had already revealed a significant stimulus by the fungus Glomus mosseae on some Paenibacillus spp. as well as particular Gammaproteobacteria in the mycorrhizosphere. Furthermore, they argued that this selective effect was driven by fungal exudates that became available [10]. Investigated the culturable bacterial communities in the mycorrhizosphere of Glomus intraradices and showed that Paenibacillus spp. were specifically selected in this habitat. In another investigation, members of the Oxalobacteriaceae were found to be more abundant in mycorrhizal than in nonmycorrhizal root samples [16]. Previous results by Warmink and van Elsas [21] showed that 
Nazir et al. Microbiology Discovery 2013,

the bacterial numbers in the mycosphere of the ectomycorrhizal fungus Laccaria proxima were significantly higher than those in the corresponding bulk soil. Later, Warmink and colleagues [24] extended the number of fungi examined and found an enhancement of culturable Pseudomonas types in the vicinity of particular fungi, thus reinforcing the concept of selective force exerted by the fungi on the soil bacteria that are locally present.

Interestingly, the fungal-selective effect appears to affect members of a limited number of bacterial types, each one of which is strongly selected in the mycosphere. For instance, clear selective effects were found to be exerted by the fruiting bodies of the ectomycorrhizal fungi Laccaria proxima and Russula exalbicans growing in forest soil on members of the Sphingomonadaceae [3]. Major Sphingomonas groups from the examined mycospheres did not cluster with Sphingomonadaceae in public databases, which indicate that novel groups of this family were present. Interestingly, similar bacterial community structures were observed for the same fungal species from different sampling sites, whereas the corresponding bulk soil communities differed from each other [3]. This indicates a strong selective effect on similar groups of soil bacteria. Furthermore, the two fungal types selected different bacteria of the same family, indicating that different fungi exert different selective forces on soil bacteria. Along with the selective pressure exerted by fungi, the local soil conditions and (a)biotic factors also contribute to the shaping of the local bacterial communities. Nutritional status, local pH and other physico-chemical parameters thus are among the key factors that drive such communities.

We understand little about how conditions in different soils drive the establishment of bacterial communities upon infestation of a virgin area by diverse communities. Moreover, we usually ignore the effects exerted by local soil fungi on these communities. Therefore, the current exploratory study was designed to foster our understanding of the following questions:

1. Which types of bacterial communities establish when selected presterilized soils are inoculated with communities from different soils?

2. What is the effect of a locally developing soil fungus?

3. Which parameters exert the strongest effect on bacterial community establishment, nativeness, soil, soil type or a colonizing fungus?

4. Are there generalist bacteria that appear under all conditions and how abundant are these?

\section{Material and methods}

\section{Soil characteristics and experimental set-up}

Four sandy (Gieterveen-G, Buinen-B, Valthermond-V, Droevendaal-WD) and four clayey (Lelystad-L, Kollumerwaard-K, Steenharst-S, Grebbedijk-WG) were sampled freshly. The characteristics of these soils can be found in (Table 1). Bacterial communities were obtained from these soils as soil extracts,
Table 1. Soils used in this study and their characteristics.

\begin{tabular}{lccclcc}
\hline Soils & \multicolumn{9}{l}{$\begin{array}{l}\text { Percentage of } \\
\text { Clay }\end{array}$} & Silt Sand & Texture & pHw & OM (\%) \\
& 30 & 20 & 50 & Sandy clay loam & 4.5 & 3.0 \\
\hline Gieterveen (G) & 30 & 20 & 50 & Sandy clay loam & 4.3 & 3.8 \\
Buinen (B) & 5 & 40 & 55 & Sandy loam & 4.7 & 17.8 \\
Valthernond (V) & 25 & 20 & 55 & Sandy clay loam & 5.2 & 3.2 \\
Droevendaal (*WD) & 80 & 12 & 8 & Clay & 7.5 & 3.1 \\
Lelystad (L) & 30 & 50 & 20 & Silty clay loam & 7.5 & 2.9 \\
Kollumenerwaard (K) & 50 & 20 & 30 & Clay & 5.7 & 5.5 \\
Steenharst (S) & 80 & 12 & 8 & Clay & 7.5 & 5.3 \\
Grebbedijk $\left({ }^{*}\right.$ WG) & & & &
\end{tabular}

${ }^{\star}$ Droevendaal and Grebbedijk are sites from Wageningen (W). N/A: not applicable

as explained below. These were then used as the inoculant communities. These communities were added at $1-2 \times 10^{6}$ CFU per g dry soil. The four sandy (G, B, V, WD) soils were selected to serve as recipient soils for all experiments. They were sterilized by autoclaving twice. Sterility was checked by plating extracts from the soils on R2A plates and incubating the plates at $28^{\circ} \mathrm{C}$; all extracts were found to be sterile, as there was no bacterial or fungal growth on the plates, even after a week.

\section{Growth and maintenance of the fungus}

The (Basidiomycetous) fungus used in this study, i.e., Lyophyllum sp. strain Karsten (DSM2979), was grown on oat flake agar (OFA) plates, prepared with $30 \mathrm{~g}$ of oat flake (local supermarket) and $15 \mathrm{~g}$ of agar (Duchefa, Haarlem, The Netherlands), water- 1 litre, sterilized at $121^{\circ} \mathrm{C}$ for $21 \mathrm{~min}$. Once every 4 weeks, the fungal strain was transferred to fresh OFA plates for maintenance.

\section{Soil microcosms}

A microcosm system was designed, consisting of threecompartment Petri dishes (Greiner Bio-one, Frickenhausen, Germany). Two compartments were filled each with about $10 \mathrm{~g}$ of moist, sterilized soil (moisture contents corresponded to $60 \%$ of water holding capacity, bulk density [wet wt/vol] of about 1.3), yielding layers of about $4 \mathrm{~mm}$ height. The four sandy soils (G, B, V and WD) were used as matrices that received the inoculant communities. The third compartment was filled with OFA. The physical barriers between the OFA and the two soil compartments prevented compounds from the OFA from reaching the soil compartments. The barriers were overcome by the fungal hyphae, and hence outgrowth of fungal hyphae from the nutrient-rich OFA into the soil was achieved. The system was inoculated with Lyophyllum sp. strain Karsten on the OFA and incubated at $28^{\circ} \mathrm{C}$, thereby allowing colonization of the OFA plus about 1-2 $\mathrm{mm}$ of the sterile soil (prior to introduction of bacterial inocula).

Preparation of bacterial cell suspension and inoculation To prepare soil bacterial cell suspensions, all eight freshly- 


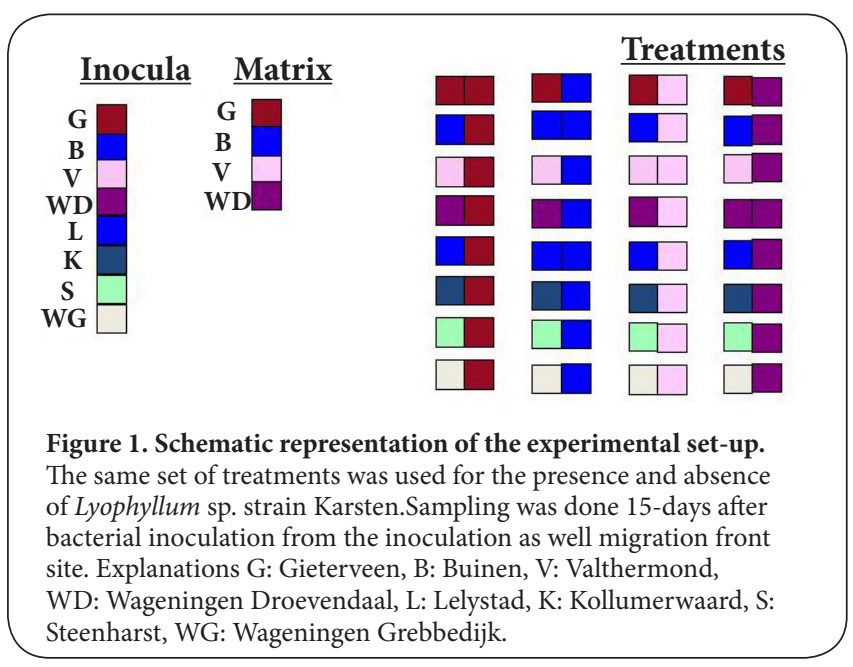

sampled soils were first homogenized and then added to sterilized milliQ water in a 1:10 proportion $(0.5 \mathrm{~g}$ of soil in 5 $\mathrm{ml}$ of water). The resulting suspensions were homogenized by vigorous shaking on a Vortex mixer (full speed; thrice for $1 \mathrm{~min})$. Following this, soil particles were allowed to settle for 10-15 min on the bench, after which 50 ul of the supernatant was used to establish the aforementioned cell densities in the soil. Briefly, the 50 ul were added by pipetting a 3-mm-wide stripe directly adjacent to the front of the growing hyphae. This inoculation into the four selected soils gave 32 different treatments (Figure 1). Control treatments without fungi received bacterial inoculation in the same fashion. Afterwards, soil microcosms were incubated at $28^{\circ} \mathrm{C}$. Samples $(100 \mathrm{mg})$ were taken at different time points (mostly at day 15) from different sites within the soil compartments (inoculation and migration front sites, using fungal-affected and unaffected microcosms) by removing 4-mm diameter cores from the soil. These samples were used for further analyses for DNA extraction as well as for cultivation-based techniques.

\section{CFU counts and isolation of strains}

Selected soil samples were vigorously shaken in $0.85 \% \mathrm{NaCl}$ buffer using a Vortex (thrice, maximum speed, one min each). Afterwards, the bacterial suspensions were diluted in a tenfold series and subsequently plated on R2A plates. CFU numbers on these plates were enumerated following incubation for $2-5$ days at $28^{\circ} \mathrm{C}$. Moreover, three colonies, primarily from the migration front site, were randomly picked for each treatment and streaked to purity. Then, these isolates were subjected to presumptive identification on the basis of their 16S rRNA gene sequence, in accordance with standard techniques [8].

\section{Extraction of DNA from soil samples}

Total soil DNA was isolated from all samples with the Ultra Clean Soil DNA isolation kit (MoBio Laboratories, Carlsbad, CA, USA, catalogue number 12800-100) according to the manufacturer's protocol. DNA purification was based on the Wizard DNA Clean-Up System kit (Promega, catalogue number 225976), which was used according to the manufacturer's protocol to remove remaining humic acids. The quality and quantity of the DNA were checked on $1 \%$ agarose gels. In all cases, DNA of about $20 \mathrm{~kb}$ average fragment size was obtained. The isolated DNA was directly used for PCR-based assessments.

As negative controls, uninoculated sterilized soils were also used in DNA extractions; no detectable DNA could be found with the used procedure.

\section{Real-time quantitative PCR (qPCR)}

Direct quantitative PCR based on the 16S rRNA gene was performed to assess the densities of total bacteria. Furthermore, the primer pair hrcR-F (GCGATCATCGTCTCGGTGTA) and hrcR-R (CGAACGCAGGA AGAACTGTC) was designed specifically to target the canonical Burkholderia terrae type $h r c R$ gene as a proxy for the presence of a type three secretion system (T3SS). DNA templates (1 ng per reaction) with SYBR Green qPCR master mix (Maxima, Applied Biosystem) was used to quantify the 16S rRNA as well as hrcR gene copy abundance. One $\mu$ l of each DNA sample was used as the template in a $25-\mu \mathrm{l}$ qPCR reaction containing $10 \mathrm{nM}$ of each primer and $1 \times$ Maxima qPCR SYBR green master mix (11.5 ul). Real-time PCR was performed using an $A B$ 7300 thermal cycler (Applied Biosystems) with the following conditions: initial cycle $95^{\circ} \mathrm{C}$ for $15 \mathrm{~min}$ and 40 cycles of: $95^{\circ} \mathrm{C}$ for $20 \mathrm{~s} ; 57^{\circ} \mathrm{C}$ for $20 \mathrm{~s}$ and $72^{\circ} \mathrm{C}$ for $30 \mathrm{~s}$. The threshold cycle $(\mathrm{Ct})$ was determined by SYBR Green incorporation into double-stranded DNA. These $\mathrm{Ct}$ values identified the PCR cycle number at which the amplicon numbers exceeded the detection limit. The relative standard curve method was applied to estimate the gene copy numbers.

\section{Analysis of total bacterial community structure with PCR-DGGE}

All soil DNA samples were subjected to $P C R$ with bacterial primers F968-GC and 1378R [15,7] using the GeneAmp PCR System 9700 (Applied Biosystems). The 50 ul PCR mix consisted of 5 ul 10x Stoffel buffer (Roche), $200 \mathrm{mM}$ of each deoxynucleoside triphosphate, $400 \mathrm{nM}$ of each primer, $1 \%$ formamide, 0.05U Stoffel Taq DNA polymerase (Roche), 31 ul $\mathrm{H}_{2} \mathrm{O}$ and $1 \mathrm{ul}$ (about $20 \mathrm{ng}$ ) of soil DNA. The following touchdown PCR program was used: $94^{\circ} \mathrm{C}$ for $3 \mathrm{~min} ; 94^{\circ} \mathrm{C}$ for $1 \mathrm{~min}, 65^{\circ} \mathrm{C}$ (decrease per cycle $1^{\circ} \mathrm{C}$ ) for $1 \mathrm{~min}, 72^{\circ} \mathrm{C}$ for $3 \mathrm{~min}$ ( 10 cycles); $94^{\circ} \mathrm{C}$ for $1 \mathrm{~min}, 55^{\circ} \mathrm{C}$ for $1 \mathrm{~min}, 72^{\circ} \mathrm{C}$ for $3 \mathrm{~min}$ ( 35 cycles); $72^{\circ} \mathrm{C}$ for $30 \mathrm{~min}$. PCR products were checked for quantity and quality by electrophoresis in $1 \%$ agarose gels. PCR products were then used in denaturing gradient gel electrophoresis (DGGE) analyses. DGGE was performed on a PhorU2 system (Ingeny International, Goes, The Netherlands) according to the manufacturer's protocol, using a gradient (Muyzer et al., 1993) of $40 \%$ to $60 \%$ denaturants (ureum/formamide) ( $100 \%$ denaturants is $8 \mathrm{M}$ 
Nazir et al. Microbiology Discovery 2013,

urea plus $40 \%$ formamide), a buffer temperature of $60^{\circ} \mathrm{C}$ and $110 \mathrm{~V}$ for $18 \mathrm{~h}$. Following electrophoresis, the polyacrylamide gels were stained using SYBR green.

\section{Analysis of community profiles and statistics}

The patterns generated via PCR-DGGE were evaluated with the program GelComparll (AppliedMaths, Sint-Martens-Latem, Belgium). As a proxy for bacterial richness, we used band (species) richness $S$; Species richness $S$ was thus defined as the number of DGGE detected bands. Evenness was estimated on the basis of the relative band intensities. Together, this yielded the Shannon-Wiener index of bacterial diversity, $\mathrm{H}$. which characterizes the diversity of the dominant species in soil microbial community $(>0.1 \%)$ according to Gelsomino et al., [6]. These data were used to determine the influence of $L$. $s p$. strain Karsten on the diversity of the dominant members of the soil bacterial community. The Shannon-Wiener index was calculated as $H=-\sum P_{i} \log P_{i}$ based on the relative band intensities $\left(P_{i}\right)$ as formulated by Eichner [5]. Means and standard deviations of $S$ and $H$ were calculated for every treatment. Clustering was done using the unweighted pair group method with mathematical averages (UPGMA) [5].

\section{Results}

Lyophyllum sp. strain Karsten colonization and effect of bacterial inocula

Growing from the OFA compartment, L. sp. strain Karsten started to colonize the uninoculated soil matrices in the microcosms as from day zero. The fungal growth rates varied in the different soil matrices, from a minimum $(1.7 \mathrm{~mm} /$ day $)$ in the $V$ soil to a maximum ( $4.4 \mathrm{~mm} /$ day) in the WD soil. The growth rates were 2.6 and $3.6 \mathrm{~mm} /$ day in the B and G soils, respectively. These growth rates were in line with the organic matter contents of the soils, which were highest in soil $\mathrm{V}$ $(17.8 \%)$ and lower in the G, B and WD soils (respectively 3.0, 3.8 and 3.2\%). Moreover, the most growth-permissive WD soil appeared to be most porous.

The presence of a bacterial community, on the other hand, caused decreases in the fungal growth rates. Grossly, these rates were constant over time, but had dropped to between 1.5 and $1.0 \mathrm{~mm} /$ day for all four (WD, V, B and G) sandy soil matrices. We could not discern any statistical differences in such rates, although different bacterial communities had different visual effects on fungal colonization. Importantly, fungal growth was never fully inhibited by the presence of any bacterial inoculum. Thus, a hyphal migration front was consistently found to move from the point of entrance adjacent to the OFA compartment towards the edge of the soil compartment within experimental time for all the treatments in the four sandy soil matrices.

Bacterial community establishment in the soil matrices Bacterial abundance in the soil matrices

Samples taken after $15 \mathrm{~d}$ from the inoculation and migration
Table 2. Bacterial community establishment in different soil matrices.

\begin{tabular}{|c|c|c|c|c|c|}
\hline & \multirow[t]{2}{*}{$\begin{array}{c}\text { Soil } \\
\text { matrices }\end{array}$} & \multicolumn{2}{|c|}{$\begin{array}{l}\text { Without colonization of } \\
\text { L. sp. Strain Karsten }\end{array}$} & \multicolumn{2}{|c|}{$\begin{array}{l}\text { With the colonization of } \\
\text { L.sp. Strain Karsten }\end{array}$} \\
\hline & & Inoculation site & $\begin{array}{l}\text { Migrartion } \\
\text { front }\end{array}$ & Inoculation site & $\begin{array}{l}\text { Migrartion } \\
\text { front }\end{array}$ \\
\hline \multirow{4}{*}{ 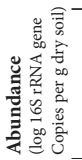 } & G & $7.85(0.35)$ & $\mathrm{BD}$ & $8.14(0.35)$ & $8.27(0.37)$ \\
\hline & B & $8.24(0.27)$ & $\mathrm{BD}$ & $8.10(0.31)$ & $8.34(0.30)$ \\
\hline & $\mathrm{V}$ & $7.84(0.45)$ & $\mathrm{BD}$ & $8.14(0.38)$ & $8.17(0.53)$ \\
\hline & WD & $7.94(0.17)$ & $\mathrm{BD}$ & $8.04(0.28)$ & $8.27(0.31)$ \\
\hline \multirow{4}{*}{ 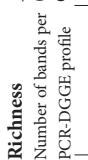 } & G & $29(3.2)$ & N/A & $23(4.7)$ & $19(4.2)$ \\
\hline & $\mathrm{B}$ & $32(4.1)$ & N/A & $25(5.0)$ & $17(5.2)$ \\
\hline & $\mathrm{V}$ & $33(5.0)$ & $\mathrm{N} / \mathrm{A}$ & $20(6.0)$ & $14(5.0)$ \\
\hline & WD & $29(4.5)$ & N/A & $19(8.7)$ & $12(8.7)$ \\
\hline \multirow{4}{*}{ 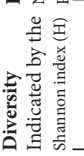 } & G & $3.29(0.13)$ & N/A & $2.97(0.29)$ & $2.76(0.33)$ \\
\hline & B & $3.37(0.15)$ & N/A & $31.4(0.23)$ & $2.71(0.33)$ \\
\hline & $\mathrm{V}$ & $3.40(0.16)$ & N/A & $2.84(0.77)$ & $2.08(0.93)$ \\
\hline & WD & $3.26(0.20)$ & N/A & $2.77(0.69)$ & $2.21(0.87)$ \\
\hline
\end{tabular}

Notes: BD: below detextion (102 gene copies per g dry soil). N/A: not applicable

front sites, both in fungal-less and fungal-containing microcosms, were subjected to dilution plating and DNA extraction. This yielded CFU counts as well as counts of $16 \mathrm{~S}$ rRNA gene copies. The CFU counts revealed the presence of culturable bacterial communities on the order of $10^{8}$ per $\mathrm{g}$ dry soil across all treatments and sites studied. However, the (uninoculated) virtual fungal migration sites in the fungal-less systems yielded no CFUs. Across the board, the bacterial quantitative $P C R$ revealed bacterial communities in the range corresponding with 16S rRNA gene copy numbers of about $1-5 \times 10^{8}$ per $g$ of dry soil, except for the extracts obtained from the virtual migration site in the fungal-less systems in which such genes were below the detection limit (Table 2). These observations confirmed the occurrence of (1) colonization of all recipient soils by the introduced microbial communities regardless of the origin of this microbiota or colonization by the fungus $L$. sp. strain Karsten, and (2) migration of the bacterial communities with the fungus towards the edge of the Petri dish. Compared to the applied inoculum level of about $10^{6}$ per $\mathrm{g}$ dry soil, it was also found that, in all cases, bacterial growth and colonization of the soil matrices took place. Thus, in all soil matrices the bacterial densities increased in the soil, also in the presence of $L$. sp strain Karsten (Table 2).

\section{Bacterial diversities in the soil matrices}

We compared the established bacterial communities (after 15 days) in their native as well as their non-native soils. All "native" communities re-established in their own soils, at "richness" values of about 32 to 37 (based on numbers of bands; depicting the dominant bacterial types), as evidenced by the PCR-DGGE profiles (data not shown). The soil matrix that allowed the highest discernible native diversity (37 bands) to establish was soil B (Figure 2). Furthermore, the non-native communities were established in all four matrices 

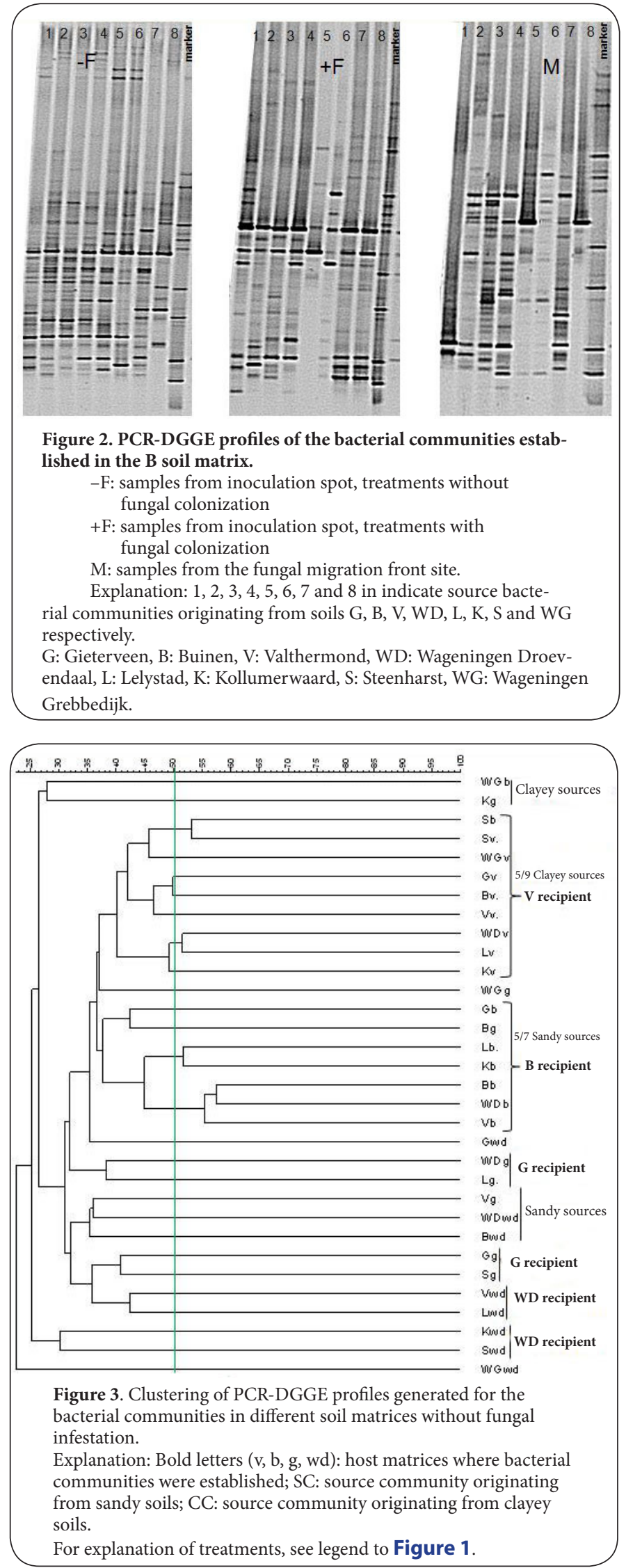

at between a minimum of 22 and a maximum of 40 bands (treatments WGwd and Gv, respectively). We then analyzed what richness, on average, could be established per recipient soil matrix. The analyses revealed the $B$ and $V$ soil matrices to allow a higher richness (33 bands) than the $G$ and WD soil matrices (29 bands). Conversely, it was found that the sandy soil source communities, i.e., from soils $G, B, V$ and $W D$, established at a richness of the dominant bacteria ranging from 29 to 40 bands in the recipient soil matrices; this tended to be higher than the non-native communities originating from the clayey soils $L, K, S, W G$, which established at richness values ranging from 22 to 36 bands.

Clearly, recipient soil matrix, possibly directed by the soil intrinsic organic matter (OM) content, was the major driver of the community structures established after 15 days, as evidenced by PCR-DGGE (Figure 3). From the figure, it appears that the $V$ and $B$ soils were, thus, strong determinants of the community structures. Eight out of the eight source communities that entered the $V$ soil clustered together in a cluster denoted $\mathrm{V}$ (soil with the highest $\mathrm{OM}$ ), whereas $6 / 8$ clustered in one denoted $B$ (soil moderate in $\mathrm{OM}$ ). Furthermore, there was one mixed WD / G soil cluster (both soils relatively low in OM). Interestingly, in the B cluster five source communities had a sandy soil origin. On the other hand, four source communities in the V cluster were from sandy soils, and five from clayey ones.

\section{Bacterial community establishment and the effect of fungal colonization}

The presence of the fungus $L . s p$. strain Karsten tended to diminish the diversities of the established dominant bacterial communities (Table 2), as indicated by using the Shannon index $\left(\mathrm{H}^{\prime}\right)$ as a proxy and comparing the fungalcolonized soil to the one without fungus. Along with the $\mathrm{H}^{\prime}$ values, bacterial richness also tended to decrease in the fungal-affected treatments compared to the ones without fungus (Table 2). In the fungal treatments, there was a clear difference between the communities at the inoculation and migration front sites. The richness in these communities was significantly lower at the migration front site than that at the inoculation site $(P<0.05)$, indicating a selective process.

We then analyzed the PCR-DGGE patterns from all samples and treatments by principle components analysis (PCA), as shown in (Figure 4). The ordination revealed complex, yet differentiating trends. A major discernible driver of bacterial community structure was the presence or absence of the colonizing fungus $L$. $s p$. strain Karsten, as evidenced from the clear separation of the relevant groups of data points along the two ordination axes (Figure 4). Interestingly, the points indicating the communities with the fungus at the inoculation site appeared at positions roughly intermediate between the ones representing the non-fungal soil samples (right) and the ones from the fungal migration front (cluster top left). The "fungal-colonized" cluster could further be 
Nazir et al. Microbiology Discovery 2013,
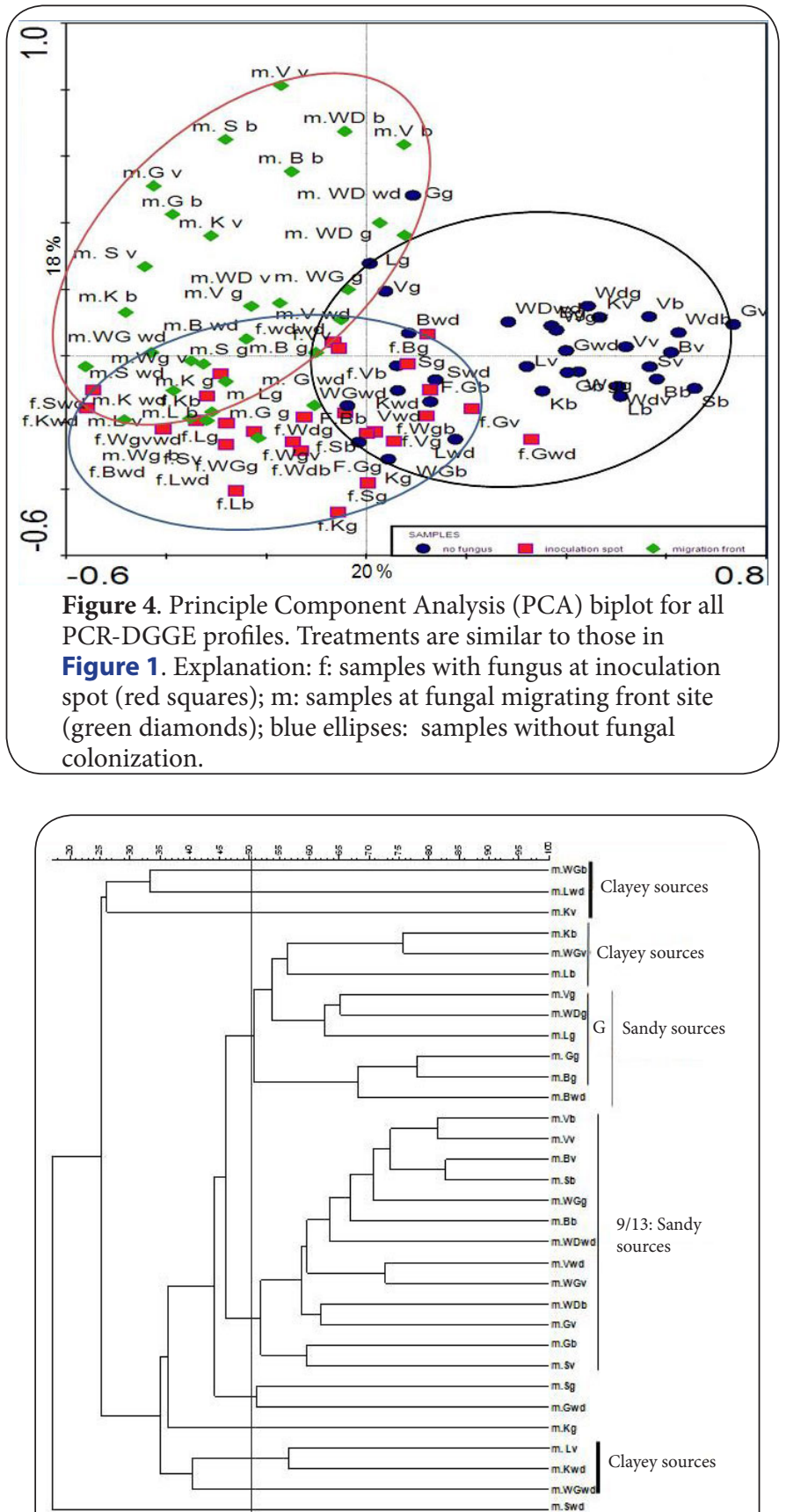

Figure 5. Clustering of PCR-DGGE profiles generated for the bacterial communities in different soil matrices with fungal infestation at migration front site. Bold letter (g): host matrix where established bacterial communities were grouped together; SC: source community originating from sandy soils; CC: source community originating from clayey soils. For explanation of treatments, see legend to Figure 1.

differentiated into two subclusters, i.e., a lower-left one encompassing the inoculation spot communities and an upper-left one containing the migration front communities.

UPGMA-based cluster analysis of the PCR-DGGE community profiles from the migration front sites in the fungal-affected microcosms revealed two large distinct clusters (Figure 5). The largest cluster encompassed 13 profiles from mixed soil matrices, nine of which had received sandy soil source communities (1, 5, 5 and 2 communities, respectively, in the $G, B, V$ and Wd matrices). Thus, the clustering of these fungal migration selected communities was mainly driven by the source communities rather than by the recipient soil matrices. The other large cluster contained nine profiles of communities across different soil matrices, six originating from sandy and three from clayey source communities. Two smaller clusters were also found, encompassing profiles from clayey soil source communities. The remainder of the community profiles (4) was mixed and could not be ascribed either to source community or soil matrix as the driver.

Enrichment of the type three secretion system (T3SS) as evidenced by quantification of the $h r c R$ gene

The B. terrae BS001 type $h r c R$ gene was used as a proxy for the T3SS to evaluate its putative enrichment in the experimental set-ups. We thus analyzed the abundance of this gene across all soils and treatments. First, it could not be detected in the presterilized uninoculated soils. Also, the abundance of $h r c R$ in the soils 15 days following inoculation was very low in the absence of the fungus, i.e., between "below the detection limit" (about $5 \times 10^{2}$ gene copies per $\mathrm{g}$ dry soil) and about $10^{3}$ gene copies per g dry soil (eg., in treatment Lv). Interestingly, fungal colonization enhanced the abundance of the B. terrae BSO01 - specific hrcR gene to up to $10^{8}$ copies per $\mathrm{g}$ soil, both at the inoculation sites (eg., in treatments $\mathrm{Gb}, \mathrm{Vb}$ and $\mathrm{Lv}$ as 2.6, 4.4 and $3.9 \mathrm{log}$ gene copies per g dry soil respectively) and migration fronts (eg., treatments $\mathrm{Bb}$, WDb, WDwd and Gwd as 2.3, 8.0, 5.9 and 3.4 log gene copies per $\mathrm{g}$ dry soil respectively). Compared to the treatments without fungal colonization, there was, thus, a significant increase in the abundance of this gene in the presence of L. sp. strain Karsten $(\mathrm{P}<0.05)$ regardless of the sampling site (inoculation or migration site). The hrcR (B. terrae type) enrichment by fungal colonization was particularly evident in the $B$ and WD soil matrices (as mentioned above), where several non-native source communities appeared to result in a similar enrichment rate.

\section{Culturable bacterial communities}

As indicated in the foregoing, the bacterial CFU counts taken from the inoculation and migration front sites revealed the presence of, roughly, $10^{8} \mathrm{CFU}$ per $\mathrm{g}$ soil in all the experimental treatments (soils), indicating bacterial growth and niche occupancy. A suite of different morphological types was present on the plates obtained from each sample. Therefore, around 200 random isolates were picked from the bacterial growth plates (R2A; at least three colonies per treatment) prepared from the inoculation and migration front sites. A selection of these was streaked to purity and tentatively identified via partial $16 \mathrm{~S} r R N A$ gene sequencing. The data 


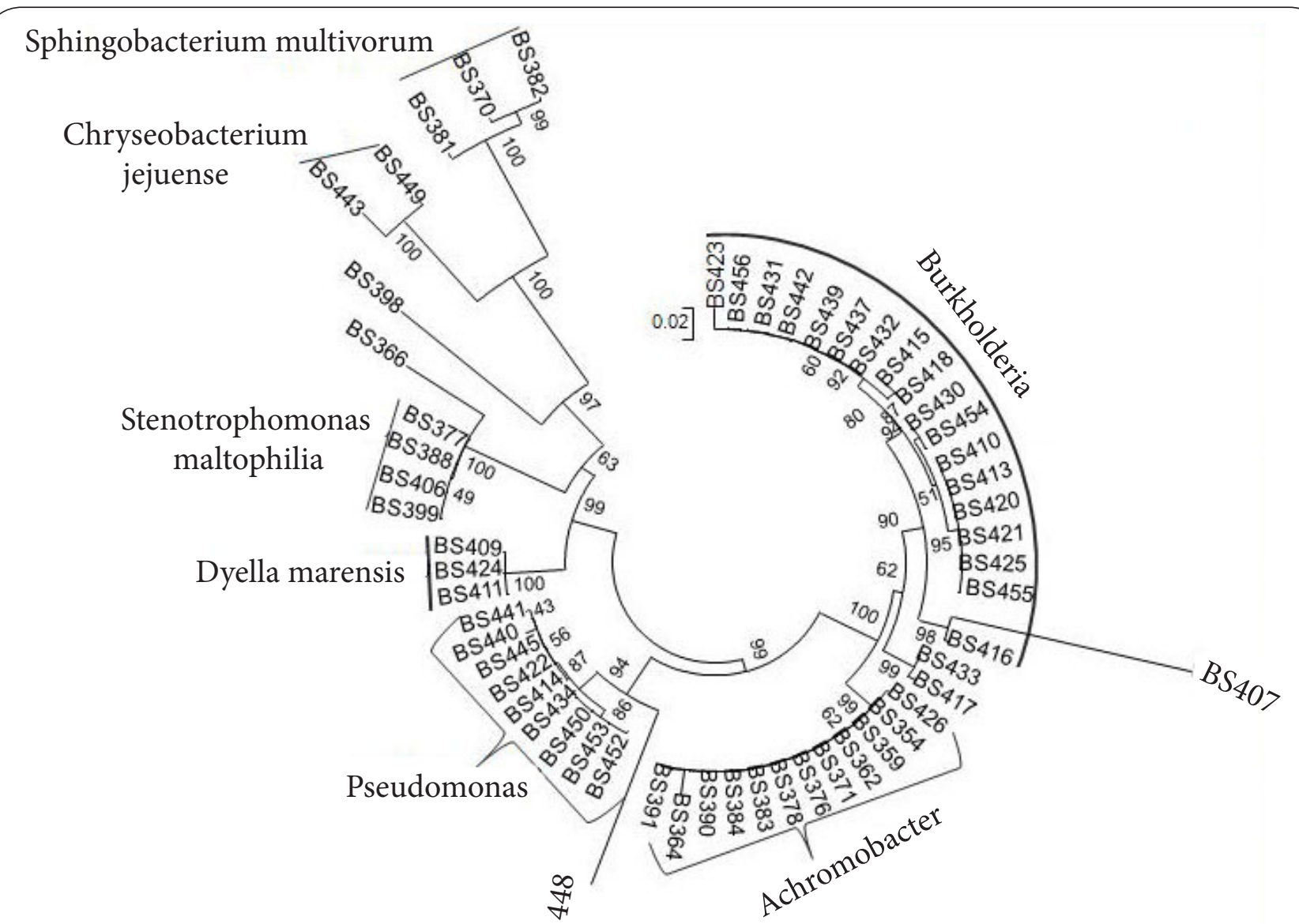

Figure 6. Bacterial strains isolated from the migration front of Lyophyllum sp. strain Karsten from different soil matrices. The phylogenetic tree was constructed on the basis of neighbour-joining using partial 16S rRNA gene sequences.

affirmed that fungal colonization selected particular bacterial types via migration in the mycosphere. Strains belonging to the genera Burkholderia, Pseudomonas and Achromobacter were prevalent at the migration front as compared to those at the inoculation site. Detailed analysis of the strains isolated from the migration front sites revealed the isolation of three big clusters encompassing strains from the genera Burkholderia, Pseudomonas and Achromobacter xylosoxidans (Figure 6). In addition to these major clusters, four smaller groups consisting of strains affiliated with Stenotrophomonas maltophilia, Sphingobacterium multivorum, Dyella marensis and Chryseobacterium jejuense were found (Figure 6). Pandorea and Staphylococcus were found as well. Out of the 19 strains belonging to the genus Burkholderia, nine belonged to the B. terrae/B. hospita cluster, while six, two and one belonged to B. phytofirmans, B. terricola and B. xenovorans, respectively. One other Burkholderia strain, i.e., BS407, was remotely related to any other described species. The strains affiliated with Pseudomonas were further identified as $P$. putida (6) and $P$. fluorescens (3). Except for two Burkholderia sp. strains (BS454 and BS455), all cultured bacterial strains originated from sandy soils (Table 3). Interestingly, all three Dyella strains originated from the $G$ soil, regardless of selection by the fungus in the $G$ or B soil matrices. Likewise, four out of five Stenotrophomonas maltophilia strains originating from the $\mathrm{G}$ soil were enriched in the $G$ and $B$ soil matrices, while the $5^{\text {th }}$ was from the $V v$ sample. Sphingobacterium multivorum, on the other hand, was enriched in the $B$ soil matrix, while originating from the $G$ and $B$ source communities. Six out of twelve Achromobacter xylosoxidans strains were selected at the migration front in the B soil matrix, and four, two and zero, respectively, in the $G, V$ and WD soil matrices. All these strains originated from different sources (Table 3, Figure 6).

\section{Discussion}

To foster our knowledge of how soil microbial communities function, it is primordial to understand the assembly rules that govern the patterns of bacterial community establishment. An excellent strategy to assess these rules is provided by soil inoculation experiments, in which microbial communities obtained from one soil are added to selected presterilized soils and the establishment of particular community structures is compared. This study provides data that support an analysis of the foundations of the bacterial community establishment.

A first strong conclusion that could be obtained from our data was, expectedly, that local soil conditions are very 
Nazir et al. Microbiology Discovery 2013,

http://www.hoajonline.com/journals/pdf/2052-6180-1-8.pdf

doi: $10.7243 / 2052-6180-1-8$

Table 3. Representatives of culturable bacterial communities from fungal migration front.

\begin{tabular}{|c|c|c|c|c|c|c|c|}
\hline $\begin{array}{l}\text { Source } \\
\text { Matrix }\end{array}$ & G & B & V & WD & $\mathbf{L}$ & $\mathbf{K}$ & \\
\hline G & BS407, BS410 & . & BS413,BS415,BS416 & BS418 & . & . & 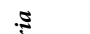 \\
\hline B & BS423,BS420,BS421,BS425 & BS430 & . & BS437,BS739 & . & . & క్ \\
\hline V & BS456 & . & BS442 & BS432 & BS454 & BS455 & 竎 \\
\hline WD & . & . & . & BS431 & . & . & \\
\hline G & BS354 & . & BS362 & BS364 & . & . & \\
\hline B & BS371,BS376,BS359 & BS426,BS378 & . & BS383,BS384 & . & . & \\
\hline $\mathrm{V}$ & . & . & BS390,BS391 & . & . & . & \\
\hline WD & . & . & . & . & . & . & \\
\hline G & . & . & BS414 & . & . & . & \\
\hline B & BS422 & . & BS434 & BS440,BS441 & . & . & 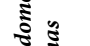 \\
\hline $\mathrm{V}$ & . & . & BS445 & . & . & . & \\
\hline WD & BS450 & BS453 & BS452 & . & . & . & \\
\hline G & BS399,BS406 & . & . & . & . & . & \\
\hline B & BS377 & . & . & . & . & . & \\
\hline $\mathrm{V}$ & . & BS388 & . & . & . & . & \\
\hline WD & . & . & . & . & . & . & \\
\hline G & BS409,BS411 & . & . & . & . & . & \\
\hline B & BS424 & . & . & . & . & . & $\Xi$ \\
\hline $\mathrm{V}$ & . & . & . & . & . & . & $\hat{\theta}$ \\
\hline WD & . & . & . & . & . & . & \\
\hline G & . & . & . & . & . & . & \\
\hline B & . & . & . & . & . & . & 3 \\
\hline $\mathrm{V}$ & . & . & BS443 & . & . & . & $\Xi$ \\
\hline WD & BS449 & . & . & . & . & . & \\
\hline G & . & . & . & . & . & . & ミ \\
\hline B & BS370 & BS381,BS382 & . & . & . & . & 每 \\
\hline $\mathrm{V}$ & . & . & . & . & . & . & 5 \\
\hline WD & . & . & . & . & . & . & \\
\hline
\end{tabular}

Footnote: we were unable to identify the strains at fungal migration front from S and WG soil sources.

"." means no sequence identified from this specific treatment.

${ }^{\star}$ Burkholderia genus represents B. terrae/ hospita, B. phytofrimans, B. xenovorans and B. terricola.

${ }^{*}$ Pseudomonas genus represents $P$. fluorescens and P. putida.

important for invading (native as well as non-native) bacterial communities to establish. These local conditions were found to cause significant differences in the established communities as a whole. Previous studies have shown the importance of soil factors, in particular soil pH and OM (sources of carbon and nitrogen) content $[13,18]$, in shaping the local microbial communities. Bacteria living in varying soil conditions may have adapted over evolutionary time to these determinative local soil parameters. Considering our data, there was a clear trend in the clustering of the establishing communities as directed by the soil matrix type, even when the communities originated from different soil sources. However, and in particular under the influence of the soil saprotrophic fungus $L$. $s p$. strain Karsten, we could also distinguish a grouping of the bacterial communities by their "broad" origin, i.e., originating from clayey versus sandy soil sources (Figure 3 ). Thus, the presence of a soil-colonizing fungus represents a key factor that governs bacterial community establishment in a new environment. In our study and similar to previous studies [24], the presence of L. sp. strain Karsten was found to restrict the bacterial diversity at the fungus. This was evidenced by the fungal-infested treatment (migration front site) being generally less diverse than the non-fungal one. Finally, the presence of particular bacteria uniquely at the fungal migration front identified these as community migrators. Clearly, and in line with previous work [12,22], this indicated the capability of such organisms to benefit from the available mycelial network, for instance for nutrition and possibly also shelter. It was striking that this capacity appeared to be present in the bacterial source communities obtained from six out of the eight soils and migrating through all four selected sandy soil matrices. Hence, bacterial movement with growing hyphae is apparently a ubiquitous phenomenon that offers ecological opportunities to the successful bacterial types.

Concerning the culturable bacteria found at the fungal migration front, the majority of the strains originated from sandy soil sources with only two isolates originating from the clayey soils $L$ and $K$. It has been reported that fungal infestation is lower in the less porous clayey soils than in sandy ones and hence the bacteria living in the former soils may not be well adapted to be selected by a colonizing fungus. From the sandy soil sources, a suite of different bacterial types 
was found to be capable of migration along with the moving hyphae of $L$. sp. strain Karsten. In particular, we found that members of the Burkholderiales increased at the migration front, especially strains from the B. terrae/hospita cluster, which indicates the migration capacity of these bacteria with the saprotrophic fungus $L$. sp. strain Karsten $[22,14]$. Moreover, we found fluorescent pseudomonads, Dyella and Chryseobacterium types at the migration front site, which coincides with earlier work in which such bacteria were found to be enriched by the mycosphere $[\mathbf{2 1}, \mathbf{2 4}]$. Furthermore, Stenotrophomonas maltophilia, Sphingobacterium spp. and Achromobacter xylosoxidans were also found to be enriched by $L$. $s p$. strain Karsten at the migration front. The presence of other bacteria at the migration front could either be the result of their own migration capability $[\mathbf{1 4 , 2 2 ]}$ or of the helper effect for co-migration along growing fungal hyphae, as was recently reported for Burkholderia terrae BS001 [23]. For instance, Dyella japonica BSO03 was found to be able to comigrate with the migration helper strain B. terrae BS001. The three strains that were found at the migration fronts together with B. terrae/B. hospita types, and that were tentatively placed in Dyella marensis (>99\% similar to D. japonica), may in fact be derivatives of the latter species, given the great similarity between these two species. Furthermore, the enrichment of the B. terrae BS001 like hrcR gene at the migration front also affirms the selection of TTSS positive $B$. terrae - like bacteria by the fungal migration front, hinting at the potential involvement of the TTSS in the interaction with the fungal host. Interestingly, TTSS has been hypothesized to be required for the bacterial migration along growing fungal hyphae, which is possibly a quite complex process that involves the action of diverse bacterial regulons [22]. Our data support the contention that the TTSS is part of an interactive gene circuit in B. terrae - like organisms, as both such Burkholderia types and the TTSS were enriched by the migration front of $L$. sp. strain Karsten moving through different soil matrices.

\section{Competing interests}

The authors declare that they have no competing interests.

\section{Authors' contributions}

Rashid Nazir planned and executed the research experiments and the analyses were further assisted in laboratory by Nermin Sarigul. Alexander V. Semenov helped in statistical analysis. The manuscript was written by Rashid Nazir and was further improved by Alexander V. Semenov and Jan D. van Elsas.

\section{Acknowledgement}

We gratefully acknowledge the technical assistance of Miaozhi Zhang with the qPCR assays. HEC Pakistan and the Soil Biotechnology Foundation (Groningen) are appreciated for their financial support to RN.

Publication history

Received: 29-Jan-2013 Revised: 25-Apr-2013

Accepted: 26-Apr-2013 Published: 17-May-2013

\section{References}

1. Artursson $\mathrm{V}$ : Bacterial-fungal interactions highlighted using microbiomics: potential application for plant growth enhancement. Uppsala university Sweden, 2005. I Pdf

2. Artursson V, Finlay RD and Jansson JK: Interactions between arbuscular mycorrhizal fungi and bacteria and their potential for stimulating plant growth. Environ Microbiol 2006, 8:1-10. | Article | PubMed

3. Boersma FG, Warmink JA, Andreote FA and van Elsas JD: Selection of Sphingomonadaceae at the base of Laccaria proxima and Russula exalbicans fruiting bodies. Appl Environ Microbiol 2009, 75:1979-89 9. | Article | PubMed Abstract | PubMed Full Text

4. Boer W, Folman LB, Summerbell RC and Boddy L: Living in a fungal world: impact of fungi on soil bacterial niche development. FEMS Microbiol Rev 2005, 29:795-811. | Article | PubMed

5. Eichner CA, Erb RW, Timmis KN and Wagner-Dobler I: Thermal gradient gel electrophoresis analysis of bioprotection from pollutant shocks in the activated sludge microbial community. Appl Environ Microbiol 1999, 65:102-9. | Article | PubMed Abstract | PubMed Full Text

6. Gelsomino A, Keijzer-Wolters AC, Cacco G and van Elsas JD: Assessment of bacterial community structure in soil by polymerase chain reaction and denaturing gradient gel electrophoresis. J Microbiol Methods 1999, 38:1-15. | Article | PubMed

7. Heuer, H. and Smalla, K: 1997 Application of denaturing gradient gel electrophoresis (DGGE) and temperature gradient gel electrophoresis (TGGE) for studying soil microbial communities. In Modern Soil Microbiology. van Elsas, J.D., Wellington, E.M.H., and Trevors, J.T. (eds). New York, NY, USA: Marcel Dekker, pp. 353-373.

8. Hirsch, P.R., Mauchline T.H and Clark I.M: Culture-independent molecular techniques for soil microbial ecology. Soil Biology \& Biochemistry 2010, 42:878-887. | Article

9. Johansson JF, Paul LR and Finlay RD: Microbial interactions in the mycorrhizosphere and their significance for sustainable agriculture. FEMS Microbiol Ecol 2004, 48:1-13. | Article | PubMed

10. Mansfeld-Giese K, Larsen J and Bodker L: Bacterial populations associated with mycelium of the arbuscular mycorrhizal fungus Glomus intraradices. FEMS Microbiol Ecol 2002, 41:133-40. | $\underline{\text { Article | }}$ PubMed

11. Muyzer G, de Waal EC and Uitterlinden AG: Profiling of complex microbial populations by denaturing gradient gel electrophoresis analysis of polymerase chain reaction-amplified genes coding for $16 \mathrm{~S}$ rRNA. Appl Environ Microbiol 1993, 59:695-700. | Article | PubMed Abstract | PubMed Full Text

12. Nazir R, Warmink JA, Boersma $H$ and van Elsas JD: Mechanisms that promote bacterial fitness in fungal-affected soil microhabitats. FEMS Microbiol Ecol 2010, 71:169-85. | Article | PubMed

13. Nazir, R., Boersma, F.G.H.,Warmink, J.A and van Elsas J.D: Lyophyllum sp. strain Karsten alleviated $\mathrm{pH}$ pressure in acid soil and enhances the survival of Variovorax paradoxus HB44 and other bacteria in the mycosphere. Soil Biology and Biochemistry 2010, 42:2146-2152. | Article

14. Nazir, R., Zhang, M., de Boer, W and van Elsas J.D: The capacity to comigrate with Lyophyllum sp. strain Karsten through different soils is spread among several phylogenetic groups within the genus Burkholderia. Soil Biology and Biochemistry 2012, 50:221-233. | Article

15. Nubel U, Engelen B, Felske A, Snaidr J, Wieshuber A, Amann RI, Ludwig $W$ and Backhaus H: Sequence heterogeneities of genes encoding $16 \mathrm{~S}$ rRNAs in Paenibacillus polymyxa detected by temperature gradient gel electrophoresis. J Bacteriol 1996, 178:5636-43. | Article | PubMed Abstract | PubMed Full Text

16. Offre $P$, Pivato B, Siblot $S$, Gamalero E, Corberand T, Lemanceau $P$ and Mougel $C$ : Identification of bacterial groups preferentially associated with mycorrhizal roots of Medicago truncatula. Appl Environ Microbiol 2007, 73:913-21. | Article | PubMed Abstract | PubMed Full Text

17. Offre P, Pivato B, Mazurier S, Siblot S, Berta G, Lemanceau P and Mougel $C$ : Microdiversity of Burkholderiales associated with mycorrhizal and nonmycorrhizal roots of Medicago truncatula. FEMS Microbiol Ecol 
Nazir et al. Microbiology Discovery 2013,

2008, 65:180-92. | Article | PubMed

18. Pereira e Silva MC, Semenov AV, van Elsas JD and Salles JF: Seasonal variations in the diversity and abundance of diazotrophic communities across soils. FEMS Microbiol Ecol 2011, 77:57-68. | Article | PubMed

19. Singh BK, Nunan N, Ridgway KP, McNicol J, Young JP, Daniell TJ, Prosser JI and Millard P: Relationship between assemblages of mycorrhizal fungi and bacteria on grass roots. Environ Microbiol 2008, 10:534-41. | Article I PubMed

20. Sneath, H.A and Sokal, R.R: Numerical taxonomy. W.H. Freeman and Company, San Francisco, 1973.

21. Warmink JA and van Elsas JD: Selection of bacterial populations in the mycosphere of Laccaria proxima: is type III secretion involved? ISME J 2008, 2:887-900. | Article | PubMed

22. Warmink JA and van Elsas JD: Migratory response of soil bacteria to Lyophyllum sp. strain Karsten in soil microcosms. Appl Environ Microbiol 2009, 75:2820-30. | Article | PubMed Abstract | PubMed Full Text

23. Warmink, J.A., Nazir, R., Corten, B and van Elsas, J.D: Hitchhikers on the fungal highway: The helper effect for bacterial migration via fungal hyphae. Soil Biology and Biochemistry 2011, 43:760-765. | Article

24. Warmink JA, Nazir R and van Elsas JD: Universal and species-specific bacterial 'fungiphiles' in the mycospheres of different basidiomycetous fungi. Environ Microbiol 2009, 11:300-12. | Article | PubMed

\section{Citation:}

Nazir R, Semenov A V, Sarigul N and van Elsas J D: Bacterial community establishment in native and non-native soils and the effect of fungal colonization. Microbiology Discovery 2013, 1:8.

http://dx.doi.org/10.7243/2052-6180-1-8 